\title{
Classification of Oecd Countries in Terms of Medical Resources and Usage with Hierarchical Clustering Analysis
}

\author{
Tibbi Kaynaklar Açısından OECD Ülkelerinin Hiyerarşik Kümeleme Analizi ile Sinıflandırılması
}

${ }^{1}$ Usak Provincial Health Directorate, Usak, Türkiye

${ }^{2}$ Eskisehir Osmangazi University, Faculty of Medicine, Department of Biostatistics, Eskisehir, Türkiye

${ }^{3}$ Eskisehir Osmangazi University Faculty of Medicine Department of Public Health, Eskisehir, Türkiye

Correspondence:

Gökçe DAĞTEKİN

Usak Provincial Health Directorate,

Usak, Türkiye

e-mail: dr_gokcetezel@hotmail.com

\section{${ }^{1}$ Gokce Dagtekin, ${ }^{2}$ Ali Kilinc, ${ }^{3}$ Ertugrul Colak, ${ }^{2}$ Alaettin Unsal, ${ }^{2}$ Didem Arslantas}

\section{Abstract}

Medical resources and usage data collected regularly and could be considered a major benchmark for countries. We aimed to classify the Organisation for Economic Co-operation and Development(OECD) member countries using the World Bank data in terms of medical resources and usage. This is a cross - sectional study. The medical resources and usage data between 2010-2015 were evaluated. Among 36 OECD member countries, 13 of them that lacked data couldn't be included in the study. Hierarchical clustering analysis was used for grouping countries with similar medical resources and usage. Although there are various methods of hierarchical clustering analysis, Ward method, has been used. Square Euclidean distance was used to obtain clusters by Ward method. Pearson correlation analysis was used to evaluate the relationship between variables. Hierarchical clustering analysis resulted in 4 clusters for selected 23 OECD countries. It was found that Turkey was in the first cluster together with Israel, Spain, Greece and Mexico. The heterogeneous clustering among the OECD countries may have been produced by the financial disparities between the countries. The results are expected to provide helpful insight on the comparison of health status.

Keywords: health indicators, medical resources, OECD, , Hierarchical Clustering Analysis

\section{Özet}

Tıbbı kaynakların kullanımına ilişkin veriler önemli sağlık göstergeleri arasında kabul edilir. Dünya Bankası verilerini kullanarak Ekonomik İşbirliği ve Kalkınma Teşkilatı (OECD) üye ülkelerini tıbbi kaynaklar ve bunların kullanımı açısından sınıflandırmayı amaçladık. Bu araștırma kesitsel tipte bir çalıșma olup; 2010-2015 yılları arasındaki tıbbi kaynaklar ve bunların kullanım verileri değerlendirildi. OECD üyesi 36 ülke arasından veri eksikliği olan 13 ülke çalışmaya dahil edilemedi. Tibbi kaynaklar ve bunların kullanımı açısından benzerlik gösteren ülkeleri saptayarak gruplayabilmek için hiyerarşik kümeleme analizi kullanıldı. Hiyerarşik kümeleme analizinin çeşitli yöntemleri olmasına rağmen Ward yöntemi kullanılmıştır. Ward yöntemiyle kümeler elde etmek için Kare Öklid mesafesi kullanıldı. Değişkenler arasındaki ilişkiyi değerlendirmek için Pearson korelasyon analizi kullanıldı. Hiyerarșik kümeleme analizi ile seçilmiș olan 23 OECD ülkesi 4 kümeye ayrıldı. Türkiye'nin İsrail, İspanya, Yunanistan ve Meksika ile birlikte ilk kümede yer aldığı tespit edildi. Sağlık göstergeleri açısından OECD ülkeleri arasındaki heterojen kümelenme, ülkeler arasındaki finansal eşitsizlik başta olmak üzere birçok faktörden kaynaklanmış olabilir. Olası faktörlerin net bir şekilde ortaya konabilmesi için daha ayrıntılı çalışmalar yapılmasına ihtiyaç duyulmaktadır.

Anahtar Kelimeler: sağlık göstergeleri, tıbbı kaynaklar, OECD, Hiyerarşik kümeleme analizi 


\section{Introduction}

Various internationally valid criterias are used to determine the health status of the societies. These criterias are used to determine the health status of societies, to evaluate the improvement over time, and to compare countries with each others, and finally for future health service plannings (1). The World Bank seperates the main health criterias into 12 topics, including background, causes of deaths, health financing, HIV / AIDS, immunization, infectious diseases, noncommunicable diseases, nutrition, population dynamics, reproductive health, water and sanitation and medical resources and usage (2).

The Organisation for Economic Co-operation and Development (OECD) is an international organisation that works to build better policies for better lives. The organisation aims to shape policies that foster prosperity, equality and opportunities for all. OECD works with governments, policy makers and citizens to build evidence-based solutions to the social and economic problems. The knowledge of differences between the member countries is critical for recommendations to improve their health policies(3).

To measure health system performances, medical resources and usage is of particular importance (4). Firstly because it's a significant determinant that demonstrates the benefits in terms of better health outcomes. The other reason being the monitoring of the number of physicians, nurses and midwives and hospital beds are objectively and easily reachable(5).

Our aim was to classify OECD countries using data from The World Bank in terms of medical resources and usage.

\section{Materials and Methods}

This cross-sectional study was conducted using OECD variables covering the year 2012. The population of the study includes data from 36 OECD member countries. The medical resources and usage data from the World bank between the years 2010-2015 were evaluated. The year 2012 was selected for the study since it had the most data from countries. The variables of the study were number of physicians, community health workers, nurses and midwives, hospital beds per thousand people and surgical procedures, specialist surgical workforce per hundred thousand population (2).

Due to the insufficient World Bank data for the year 2012, some of the variables could not be included in the analysis. The excluded data were; the number of community health workers per thousand people, surgical procedures and specialized surgical workforce per hundred thousand population.

The study was conducted on the data from Turkey, Mexico, Korea, Japan, Slovenia, the UK, Luxembourg, Belgium, Lithuania, Hungary, Finland, Israel, Estonia, Iceland, Czech Republic, Spain, Germany, Sweden, Switzerland, Lithuania, Latvia, Norway, Austria and Greece.

In this study, hierarchical clustering analysis was used for grouping countries with similar medical resources and usage. Although there are various methods of hierarchical clustering analysis, Ward method, which is one of the most common methods, has been used. Square Euclidean distance was used to obtain clusters by Ward method(6). Pearson correlation analysis was used to evaluate the relationship between variables. Data were analyzed using IBM SPSS (Version 15.0) statistical package program. Statistical significance was considered $\mathrm{p}<0.05$.

\section{Results}

Among the OECD countries included in the study, the number of hospital beds per thousand people ranged between 1.50-13.40. The number of physicians, nurses, midwives and hospital beds per thousand people in 2012 was shown in Table 1. 
Table 1. The Number of Physicians, Hospital Beds, Nurses and Midwives Per Thousand People in 2012

\begin{tabular}{|c|c|c|c|}
\hline Countries & $\begin{array}{l}\text { Number of Physicians } \\
\text { (per } 1000 \text { people) }\end{array}$ & $\begin{array}{l}\text { Number of Nurses and } \\
\text { Midwives(per } 1000 \text { people) }\end{array}$ & $\begin{array}{l}\text { Number of Hospital } \\
\text { Beds(per } 1000 \text { people) }\end{array}$ \\
\hline Germany & 3.90 & 12.90 & 8.20 \\
\hline Austria & 4.90 & 8.00 & 7.70 \\
\hline Belgium & 2.90 & 10.50 & 6.30 \\
\hline Czechia & 3.70 & 8.50 & 6.70 \\
\hline Estonia & 3.30 & 6.50 & 5.50 \\
\hline Finland & 3.10 & 14.60 & 5.30 \\
\hline United Kingdom & 2.80 & 8.70 & 2.80 \\
\hline Iceland & 3.50 & 15.80 & 3.30 \\
\hline Spain & 3.80 & 5.30 & 3.00 \\
\hline Israel & 3.30 & 5.00 & 3.10 \\
\hline Sweden & 4.00 & 11.90 & 2.60 \\
\hline Switzerland & 3.90 & 17.20 & 4.80 \\
\hline Japan & 2.30 & 10.80 & 13.40 \\
\hline Korea & 2.10 & 4.90 & 10.30 \\
\hline Latvia & 3.10 & 6.00 & 5.90 \\
\hline Lithuenia & 4.20 & 7.80 & 7.40 \\
\hline Luxemburg & 2.80 & 12.30 & 5.20 \\
\hline Hungary & 3.10 & 6.50 & 7.00 \\
\hline Mexico & 2.00 & 2.40 & 1.50 \\
\hline Norway & 4.20 & 17.10 & 4.00 \\
\hline Slovenia & 2.50 & 8.20 & 4.50 \\
\hline Turkey & 1.70 & 3.20 & 2.70 \\
\hline Greece & 6.20 & 3.60 & 4.40 \\
\hline
\end{tabular}

To refrain from autocorrelation problem between the variables, we used pearson correlation analysis and no correlation was found among the number of Physicians, nurses and midwives and hospital beds per thousand people. The relationship between the variables used in clustering analysis was given in Table 2. 
Table 2. The Relationship Between the Variables Used in Clustering Analysis

\begin{tabular}{lccc}
\hline $\begin{array}{l}\text { Variables } \\
\text { (per 1000 people) }\end{array}$ & Number of Hospital Beds & $\begin{array}{c}\text { Number of Nurses and } \\
\text { Midwives }\end{array}$ & \begin{tabular}{c} 
Number of Physicians \\
\hline $\begin{array}{l}\text { Number of Hospital Beds } \\
(p, r)\end{array}$
\end{tabular} \\
$\begin{array}{l}\text { Number of Nurses } \\
\text { and Midwives } \\
(p, r)\end{array}$ & $0.710,0.082$ & $0.710,0.082$ & $0.787,0.060$ \\
\hline $\begin{array}{l}\text { Number of Physicians } \\
(p, r)\end{array}$ & $0.787,0.060$ & --- & $0.427,0.174$ \\
\hline
\end{tabular}

The dendogram obtained by using hierarchical clustering analysis in terms of medical resources and usage data of the countries included in the research was given in Graphic 1. The 23 countries included in the study were divided into 4 clusters after the analysis.

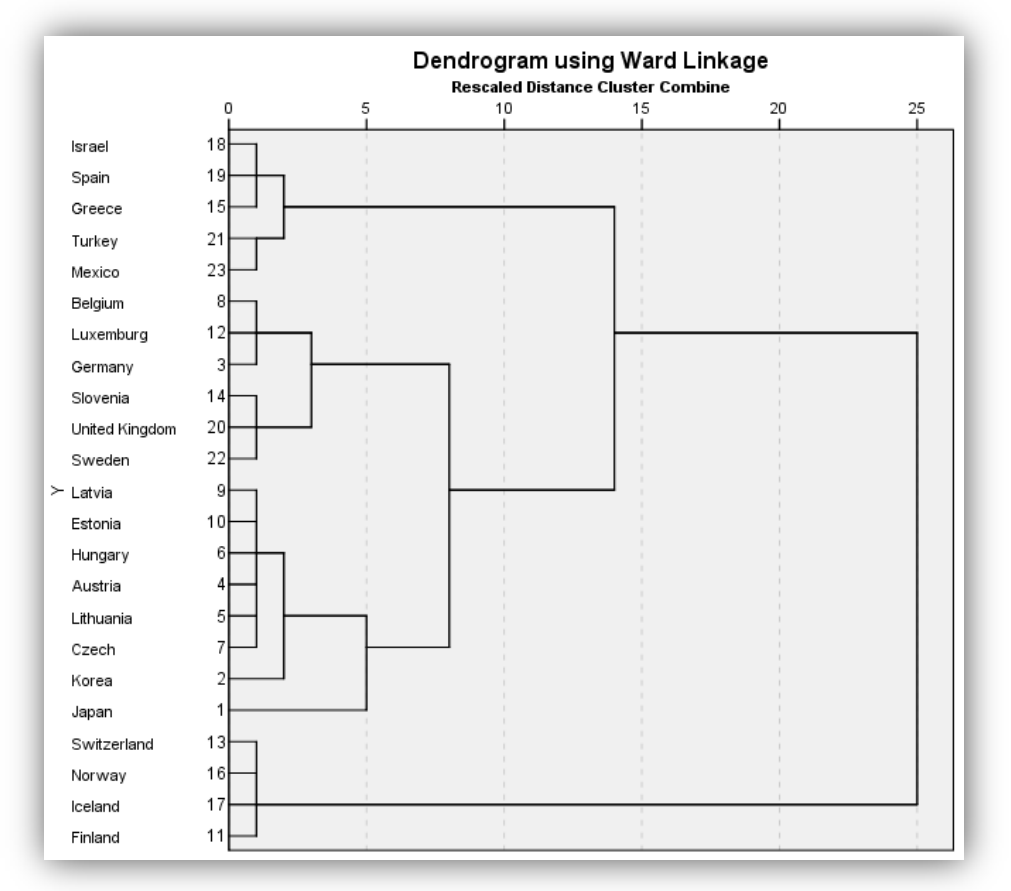

Graph 1. Dendogram Obtained According to Hierarchical Clustering Analysis in Terms of Medical Resources and Usage

\section{Discussion}

The health systems among OECD countries varies considerably(7). The measuring and comparing the performances of international health systems becomes increasingly important for policy makers $(8,9)$. With this aim in mind, international organizations such as the World Health Organization (WHO) and the OECD evaluate health systems in many aspects and provide advice on how to improve health policies $(7,10)$.

To evaluate health systems, many indicators are commonly used including disease prevention, health promotion and finance. In 
this sense, medical resources and usage is an important one of them $(2,8,10)$. When the medical resources and usage are considered, health workforce is the leading concern of policy makers (5).

As a result of the hierarchical clustering analysis made, it was seen that there were four clusters representing 23 countries. Amongst the groups formed, the first one consisted of Israel, Spain, Greece, Turkey and Mexico, the second one consisted of Belgium, Luxembourg, Germany, Slovenia, United Kingdom, Switzerland and Latvia. While the third group consisted of Estonia, Hungary, Austria, Lithuania, Czech Republic, Korea and Japan, the fourth group included Sweden, Norway, Iceland and Finland.To gain a better understanding, of the health status of the four groups, many measurements should be considered. Financial status has been shown to play a major role in the health disparities in many times $(11,12)$. Gross Domestic Product (at purchasing power parity) GDP (PPP) per capita is the most commonly used summary measure of financial status $(9,13)$. It was observed that there were indeed differences among the groups when GDP (PPP) per capita was considered. For the year 2012, the first group's average GDP (PPP) per capita was $\$ 20.998$, the second group's average GDP (PPP) per capita was \$52.188, the third group's average GDP (PPP) per capita was \$24.806 and the fourth group's average GDP (PPP) per capita was $\$ 69.295(13)$.

In a study comparing OECD countries Austria, Belgium, France, Germany and Switzerland were reported to be above average in terms of the number of physicians per population but Canada was below(11). Vehid and colleagues reported that Turkey fell short in terms of the physician density when compared to the European Union countries.(14). There are differences between OECD countries in terms of physician education, retention and retirement. Another factor that may also cause the heterogeneity among the OECD countries is their life expectancy and population growth rate are not increasing cohorently with their health workforce and medical resources and usage(11). It is clear that increasing the number of physicians per population will lead to an increase in health expenditures. However, selected OECD countries have differing health expenditure as percentage of GDP which results in clustering. Nursing and midwifery services are both essential and expensive for modern health systems. The global economic crisis in 2008 and beyond have reduced the government budgets and consequently nursing and midwifery personnel that are employed mostly by the governments. A decrease in employment in the health sector was parallel with to what degree countries have been affected by the 2008 economic crisis can be considered one reason for this clustering $(5,11,15)$.

In this study, no correlation was found between the selected health indicators. While the number of physicians and nurses have been increasing regularly in OECD countries since 2000 , there has been a decrease in the number of hospital beds and the average length of hospital stay $(9,16)$. The advances on medical technologies and surgical procedures have resulted in decreased amount of hospital stay therefore the need for hospital beds are on decline. Furthermore, the decline in public funding of health following the economic crisis in 2008, may have contributed to the decrease in the number of hospital beds $(9,17)$. The findings obtained from our study can be interpreted to be consistent in this context.

The World bank database suffers from missing medical resources and usage data. It may have caused a bias in the study.

In conclusion medical resources and usage are an important indicator in measuring the performance of health systems. By using the World Bank 2012 data set, it was observed that 23 OECD countries divides into 4 clusters in terms of medical resources and usage. Differences in health systems and economic conditions of countries were thought to have an impact on this heterogeneity. More comprehensive studies are needed to compare countries' health indicators and to produce new policies. 


\section{REFERENCES}

1. Commission E. European Core Health Indicators [Available from: https://ec.europa.eu/health/indicators/echi/list_en.

2. bank w. Health, Nutrition and Population [27.05.2019]. Available from: http://datatopics.worldbank.org/health/availableindicators.

3. OECD. about [Available from: https://www.oecd.org/about/.

4. Varabyova Y, Müller J-M. The efficiency of health care production in OECD countries: A systematic review and meta-analysis of crosscountry comparisons. Health Policy. 2016;120:252-63.

5. Buchan J, O'may F, Dussault G. Nursing workforce policy and the economic crisis: a global overview. Journal of Nursing Scholarship. 2013;45:298-307.

6. Kimes PK, Liu Y, Neil Hayes D, Marron JS. Statistical significance for hierarchical clustering. Biometrics. 2017;73:811-21.

7. Arah OA, Westert GP, Hurst J, Klazinga NS. A conceptual framework for the OECD health care quality indicators project. International Journal for Quality in Health Care. 2006;18(suppl_1):513.

8. De Looper M, Lafortune G. Measuring disparities in health status and in access and use of health care in OECD countries. 2009.

9. Oecd. Health At A Glance: Europe 2018: Organization For Economic; 2018.

10. Organisation WH. Global Health Observatory (GHO) data 2019 [26.06.2019]. Available from: https://www.who.int/gho/publications/world_healt h_statistics/en/.

11. OCDE SS, Hurst J. The supply of physician services in OECD countries. OECD health working papers.

12. Retzlaff-Roberts D, Chang CF, Rubin RM. Technical efficiency in the use of health care resources: a comparison of OECD countries. Health policy. 2004;69:55-72.

13. Bank TW. GDP per capita (current US\$) 2019 [Available from: https://data.worldbank.org/indicator/ny.gdp.pcap.c d.

14. Vehid S. Temel Demografik Ve Sağlik Düzeyi Ölçütleri Açısından Türkiye İle Avrupa Birliği'ne (Ab) Üye Ülkelerin Karşılaştırılması. Cerrahpaşa Tip Dergisi.31(2).

15. Buchan J, Twigg D, Dussault G, Duffield C, Stone P. Policies to sustain the nursing workforce: an international perspective. International nursing review. 2015;62:162-70.

16. OECD. OECD Health Statistics 2019 [Available from: https://www.oecd-ilibrary.org/social-issuesmigration-health/data/oecd-healthstatistics_health-data-en.

17. Karanikolos M, Mladovsky P, Cylus J, Thomson S, Basu S, Stuckler D, et al. Financial crisis, austerity, and health in Europe. The Lancet. 2013;381:1323-31. 